\title{
COMMENTS
}

\section{Welfare and the Minimum Wage: Are Workfare Participants "Employees" Under the Fair Labor Standards Act?}

\author{
Kevin J. Miller $\dagger$
}

When President Clinton signed into law the Personal Responsibility and Work Opportunity Reconciliation Act of 1996 ("PRWORA"), ${ }^{1}$ he fulfilled his promise to "end welfare as we know it." The most significant change the PRWORA made was to increase dramatically the work requirements for welfare recipients. ${ }^{3}$ This increase is to be achieved through state-created workfare programs and by conditioning federal block grants upon states meeting minimum participation rates. Acceptable workfare programs can vary significantly by state and can include any or all of the following activities: unsubsidized or subsidized employment with either public or private employers, on-the-job training, community service, vocational training, or providing child care services to participants in community service. ${ }^{4}$

Critics have noted, however, that while the PRWORA did toughen work requirements and provide funding to states for workfare programs, it did nothing to guarantee that low-skilled

$\dagger$ B.A. 1993, University of Georgia; J.D. Candidate 1999, The University of Chicago.

1 Pub L No 104-193, 110 Stat 2105 (1996), reprinted in 1996 USCCAN 2105-2355, codified as amended in scattered sections of 42 USC.

2 William J. Clinton, Acceptance Speech at the Democratic National Convention, 1992 Democratic Convention, reprinted as '92 Democratic Convention; Clinton Text: 'I Still Believe in a Place Called Hope,' LA Times A10 (July 17, 1992).

${ }^{3}$ See Elspeth K. Deily, Working with Welfare: Can Single Mothers Manage?, 12 Berkeley Women's L J 132, 132 (1997) ("The linchpin to the [PRWORA] is encouraging selfsufficiency through work requirements."). See also Part I.A.

1 See note 22 and accompanying text. 
workers would be better prepared for employment. ${ }^{5}$ Indeed, recent evidence shows that most individuals who lose their welfare benefits do not find jobs. ${ }^{6}$ In light of this evidence, it is particularly troubling that when welfare recipients do participate in state workfare programs, courts may deny them the statutory minimum wage by holding that they are not "employees" entitled to the minimum wage guarantees of the Fair Labor Standards Act of 1938 ("FLSA"), ${ }^{7}$ notwithstanding the fact that they are doing the same work as other "employees." For example, the Tenth Circuit, the only circuit to have considered the issue, held in Johns $v$ Stewart ${ }^{8}$ that Utah's workfare participants were not "employees" entitled to FLSA protections. ${ }^{9}$ Although the FLSA's coverage is indeed broad, and although the courts have interpreted the Supreme Court's "economic realities" employment test in a manner generally favorable to employees, some courts have been willing to depart from this approach in the context of nontraditional work arrangements such as volunteer work, prison labor, student work-study programs, and now workfare..$^{10}$

This Comment argues that workfare participants generally should be considered "employees" within the meaning of the FLSA. Under the judicially created "economic realities" test and related doctrines, workfare participants often should qualify for the minimum wage; ensuring that they receive it is good policy and is consistent with the goals of both the FLSA and PRWORA. Courts are likely to face an increasing number of labor claims from the growing pool of workfare participants, ${ }^{11}$ and because the FLSA's minimum wage requirement is among the most basic la-

- See, for example, Cheryl Sullivan, Welfare in America: What is Being Reformed?, 11 Notre Dame J L Ethics \& Pub Pol 633, 633 (1997) (discussing implications and possible solutions to problems associated with welfare reform).

- See Raymond Hernandez, Most Dropped From Welfare Don't Get Jobs, NY Times A1 (Mar 23, 1998). The New York City survey, which looked at individuals who came off welfare rolls from July 1996 through March 1997, found that only 29 percent had full-time or part-time jobs within the first several months after they lost their welfare assistance. Id. See also Jason DeParle, What About Mississippi?: A special report.; Welfare Law Weighs Heavy in Delta, Where Jobs Are Few, NY Times A1 (Oct 16, 1997) (reporting that for welfare recipients in Mississippi, "almost as many people temporarily lost their benefits as landed and keptjobs").

7 Pub L No 718, 52 Stat 1060 (1938), codified as amended at 29 USC $\S \S 201$ et seq (1994)

${ }^{8} 57$ F3d 1544 (10th Cir 1995).

9 Id at 1559.

${ }^{10}$ See Part III.

${ }^{11}$ For support for this view, see David L. Gregory, Br(e)aking the Exploitation of Labor?: Tensions Regarding the Welfare Workforce, 25 Fordham Urban L J 1, 22 (1997) (stating that "litigation is certain to quickly proliferate" and noting the current dearth of caselaw). 
bor protections, ${ }^{12}$ a blanket denial of its coverage to workfare participants may sound the death knell for a variety of other federal labor law claims by workfare participants. Moreover, a denial of minimum wage coverage to workfare participants would frustrate the broad policy goals of the FLSA and could prove to be an obstacle to successful welfare reform.

Part I of this Comment sets out the general work requirements of the recent welfare reform legislation, considering the statute's legislative history and its interpretation by the Department of Labor. It also identifies a possible gap in the PRWORA's requirements that certain federal labor laws apply to workfare recipients. Part II analyzes the FLSA, including its circular text, its broad remedial purposes, and the Supreme Court-created "economic realities" test of employment, and argues that courts should apply this test on a case-by-case basis to determine whether certain workfare participants are "employees" entitled to the minimum wage. In Part III, the Comment explores courts' departures from the generally accepted application of the "economic realities" test, concluding that even courts that refuse to adopt the generally accepted application of the "economic realities" test should analyze workfare activities on a case-by-case basis rather than categorically deny workfare participants the minimum wage. Finally, Part IV offers further support for applying the FLSA to these welfare recipients, explaining that the policy goals of the PRWORA are in accord with the purposes behind the FLSA and discussing the implications of denying FLSA coverage to this class of workers.

\section{THE PERSONAL RESPONSIBILITY AND WORK OPPORTUNITY RECONCILIATION ACT OF 1996}

Title I of the PRWORA creates Temporary Assistance for Needy Families ("TANE"), replacing such programs as Aid to Families with Dependent Children ("AFDC") 13 and Job Opportunity and Basic Skills ("JOBS"), ${ }^{14}$ AFDC's work program. One of the PRWORA's main goals is "end[ing] the dependence of needy parents on government benefits by promoting job preparation, work, and marriage."15

\footnotetext{
${ }^{12}$ See Matthew Diller, Working Without a Job: The Social Messages of the New Workfare, 9 Stan L \& Pol Rev 19, 27 (1998) ("[M]inimum wage protection is one of the most rudimentary of all employee rights.").

${ }^{13} 42$ USC $\$ \S 601-17$ (1994).

${ }^{14}$ Id $\S \S 681-87$.

${ }^{15}$ PRWORA § 401(a)(2), 110 Stat at 2113.
} 


\section{A. TANF Work Requirements}

TANF replaces welfare recipients' entitlements to aid under AFDC with a block grant system that provides states with funding for creating and maintaining work programs. ${ }^{16}$ States must submit to the Department of Health and Human Services ("HHS") a plan outlining how they intend to implement a program that ensures that "parents and caretakers receiving assistance under the program engage in work activities." ${ }^{\text {17 }}$ While TANF gives states a great deal of flexibility in their implementation of these work programs, ${ }^{18}$ it also establishes strict requirements that states move recipients from welfare to work. The PRWORA requires states to engage 25 percent of all families in work activities by 1997 and mandates a minimum 50 percent participation rate by $2002 .^{19}$ Receipt of a portion of the federal block grant funds depends on states' meeting these participation rates. ${ }^{20}$

Except under extraordinary circumstances, TANF requires parents to work (a) once the state has determined they are ready to engage in work or (b) once they have received assistance under the program for two years. ${ }^{21}$ Single-parent families are required to participate for at least twenty hours per week in, among other things, unsubsidized or subsidized employment, on-the-job training, work experience, or community service. ${ }^{22}$ TANF also

${ }^{16}$ Amy Brown, Work First: How to Implement an Employment-Focused Approach to Welfare Reform (Manpower Demonstration Research Corp Mar 1997), available online at $<\mathrm{http}: / /$ aspe.os.dhhs.gov/hsp/isp/worklst/frontm.htm> (visited Sept 29, 1998); PRWORA $\S 403,110$ Stat at 2115.

${ }^{17}$ PRWORA § 402(a)(1)(A)(iii), 110 Stat at 2113.

${ }^{18}$ PRWORA § 401(a), 110 Stat at 2113 ("The purpose of this part is to increase the flexibility of States in operating [this] program."); Department of Labor ("DOL"), How Workplace Laws Apply to Welfare Recipients (May 22, 1997), available online at <http://www.dol.gov/dol/asp/public/w2w/welfare.htm\#How> (visited Nov 9, 1998) (noting that the PRWORA "gives state and tribal governments broad latitude to meet specified work requirements").

${ }^{19}$ PRWORA $\S 407(a)(1), 110$ Stat at 2129.

${ }^{20}$ See Erin Elizabeth Raccah, Note, Thrown Into the Gap: Employment Discrimination in Workfare, 18 Women's Rts L Rep 67, 68 (1996); PRWORA § 407(a), 110 Stat at 2129.

${ }^{21}$ PRWORA $\S 402(\mathrm{a})(1)(\mathrm{A})(\mathrm{ii}), 110$ Stat at 2113; HHS, Fact Sheet, The Personal Responsibility and Work Opportunity Reconciliation Act of 1996 (Aug 12, 1997), available online at <http://www.hhs.gov/news/press/1997pres/970812.html> (visited Sept 26, 1998) ("Under the new law, recipients must work after two years on assistance, with few exceptions.").

${ }^{22}$ PRWORA § 407(c)(1)(A), 110 Stat at 2131; PRWORA § 407(d), 110 Stat at 2133. See also HHS, Press Release, Comparison of Prior Law and the Personal Responsibility and Work Opportunity Reconciliation Act of 1996 (P.L. 104-193), available online at $<$ http://aspe.os.dhhs.gov/hsp/isp/reform.htm $>$ (visited Oct 21, 1998). Other available alternatives include participating in up to twelve months of vocational training or providing child care services to participants in community service. See PRWORA § 407(c)(1)(A), 110 
limits the length of time recipients can spend looking for a job before they are required to work..$^{23}$

\section{B. A Gap in the Application of Federal Labor Laws?}

As this Part will show, neither the text nor the legislative history of the PRWORA indicates whether Congress intended the FLSA to apply to workfare participants. Meanwhile, the Department of Labor ("DOL") has interpreted the PRWORA so that the FLSA applies to workfare participants in many circumstances. Although the DOL reading is not authoritative, it is a reasonable approach consistent with the test applied by courts in other cases where the statutory definition of "employee" is at issue.

\section{Text of the PRWORA.}

The text of the PRWORA does not address the applicability of the FLSA to welfare recipients participating in work activities, although the statute does contain a "Nondiscrimination Provision." As originally enacted, the PRWORA provided that the following laws apply to state programs receiving funds under TANF: (1) The Age Discrimination Act of 1975 (42 USC §§ 6101 et seq); (2) Section 504 of the Rehabilitation Act of 1973 (29 USC $\S 794$ ); (3) The Americans with Disabilities Act of 1990 (42 USC $\S \S 12101$ et seq); and (4) Title VI of the Civil Rights Act of 1964 (42 USC $\S \S 2000 d$ et seq). ${ }^{24}$ It made no mention of either the FLSA or Title VII of the Civil Rights Act. ${ }^{25}$

Possibly in response to criticism of the absence of Title VII protections, ${ }^{26}$ Congress amended the PRWORA in 1997 to provide protection against gender discrimination. ${ }^{27}$ The statute now provides protection for those participants who might not otherwise be covered by the gender discrimination provisions of either Title VII of the Civil Rights Act of 1964 or Title IX of the Education

\footnotetext{
Stat at 2131; PRWORA § 407(d), 110 Stat at 2133.

${ }^{23}$ TANF permits up to six weeks of job search, but no more than four of those weeks may be consecutive. PRWORA $\S 407(\mathrm{c})(2)(\mathrm{A})(\mathrm{i}), 110$ Stat at 2132. However, "states with unemployment rates at least $50 \%$ above the national average may count up to 12 weeks of job search" toward the TANF work requirements. HHS, Comparison of Prior Law (cited in note 22).

${ }^{24}$ PRWORA $\S 408(c)(1)-(4), 110$ Stat at 2142 (listing applicable nondiscrimination provisions).

${ }^{25}$ See Raccah, Note, 18 Women's Rts L Rep at $69-70$ (cited in note 20) (noting that "there is no mention of Title VII of the Civil Rights Act").

${ }^{26}$ See id at 71-72 (arguing that welfare -recipients, who are predominantly single mothers, need protection from gender discrimination in the workplace).

${ }^{27}$ Balanced Budget Act of $1997 \S 5001(\mathrm{a})(1)$, Pub L No 105-33, 111 Stat 251, 588 (1997), codified at 42 USCA $\S 603(a)(5)(J)(i i i)(1998)$.
} 
Amendments of $1972 .^{28}$ Yet the amended version of the statute still does not mention the applicability of the FLSA.

Because FLSA coverage was not specifically codified in the PRWORA's "Nondiscrimination Provision," it is possible that Congress intended to withhold minimum wage protection from participants in TANF's work programs. This argument gains further support from the fact that Congress failed to provide minimum wage protection when it amended the PRWORA in 1997 to include coverage of the previously overlooked protection against gender discrimination.

The fact that the PRWORA does not specifically include FLSA protection, however, does not necessarily mean that workfare participants are never entitled to the minimum wage. Just as the FLSA's failure to exempt workfare participants from its coverage explicitly does not necessarily indicate that Congress intended for the statute to apply to workfare,$^{30}$ the silence of the PRWORA's Nondiscrimination Provision with respect to the FLSA does not evince any particular legislative intent. ${ }^{31}$ In fact, it is plausible that Congress intended for the courts to determine on a case-by-case basis whether the particular workfare program or situation was within the FLSA's definition of "employment," using the "economic realities" test established by the Supreme Court. $^{32}$

${ }^{28}$ DOL, Employment and Training Administration ("ETA"), Welfare-to-Work Grants, 62 Fed Reg 61588, 61597 (1997) (noting that "participants in [Welfare-to-Work] programs have such rights as are available under any applicable Federal, State or local law prohibiting discrimination").

${ }_{29}$ PRWORA \& 408(c)(1)-(4), 110 Stat at 2142.

${ }^{30}$ See text accompanying note 60 .

${ }^{31}$ For further discussion of the argument that little about legislative intent can be gleaned from Congress's silence, see generally Daniel L. Rotenberg, Congressional Silence in the Supreme Court, 47 U Miami L Rev 375 (1992) (arguing that the Supreme Court can interpret legislative silence in virtually any way it sees fit); John Robertson, Note, "For Our Own Good:" Federal Preemption of State Tort Law-Risk, Regulation, and the Goals of Environmental Protection, 20 Wm \& Mary Envir L \& Pol Rev 143, 144 (1995) (noting that "any meaning courts may find in congressional silence is contrived at best"). See also NLRB v Plasterers' Local Union No 79, 404 US 116, 129-30 (1971) (noting the danger of adopting silence as congressional intent).

${ }^{32}$ This argument gains support from the fact that Congress can be attributed with the knowledge that the Supreme Court uses the "economic realities" test to determine if an individual is an "employee" under the FLSA. When Congress passed the PRWORA in 1996, courts had been using the "economic realities" test for over thirty years. See text accompanying notes 61-66. In other labor law contexts such as Title VII and the ADA, Congress has also failed to further define coverage of certain classes of workers. Perhaps this is because Congress feels there is some benefit in allowing courts to retain some flexibility in discerning the limits of "employee"-"employer" relationships. That is, Congress cannot foresee all possible relationships that will be tested under its statutes, but it can be confident that this is an area where courts have gained some expertise through years of adjudicating these types of issues. Furthermore, Congress may not want to provide too much 


\section{Legislative history of the PRWORA.}

Unfortunately, the legislative history of the PRWORA also does not answer the question of whether the FLSA applies to workfare participants. On the one hand, during congressional hearings on PRWORA, some groups expressed concern about the application of the FLSA and other labor statutes to the large number of welfare recipients who might participate in workfare programs. One prepared statement by a member of the U.S. Chamber of Commerce cited concerns that "[t]hese [federal labor law] statutes, while intended to establish fair and reasonable workplace relationships, carry disproportionate risks if extended to a large class of individuals who are unaccustomed to the workplace and do not find success in employment." ${ }^{33}$ This statement reflects a widespread concern that employer exposure to liability under statutes like the FLSA, combined with marginal skills of the class of welfare workers, would provide a disincentive to hire welfare workers. ${ }^{34}$

On the other hand, proponents of a minimum wage argued that the potential for displacement of current workers by a large influx of unpaid or underpaid workfare participants could "further depress the plummeting wages of low-skilled workers."35 They argued that, at a minimum, the PRWORA should require adherence to basic labor standards such as the FLSA, and "[i]deally welfare reform should establish clear requirements for equal pay and benefits for equal work.."36 The American Federation of State, County and Municipal Employees argued that fairness concerns required that welfare recipients who performed the same work as other employees "should enjoy the same wages, rights and benefits." ${ }^{\prime 37}$ Otherwise, they argued, workfare programs could undermine labor-management relationships and "contribute to a further weakening of wages in the low-wage labor market."38

specificity, as that would allow unscrupulous employers to easily evade the strict letter of the law. For further discussion of the "economic realities" test of employment, see Part II.B.

${ }^{33}$ Welfare to Work, Hearing on 104-140 before the Senate Committee on Finance, 104th Cong, Ist Sess 63 (1995) (prepared statement of Jeffrey H. Joseph, Chamber of Commerce of the United States).

${ }^{34}$ See id.

${ }^{35}$ Id at 79 (prepared statement of Gerald M. Shea, AFL-CIO).

${ }^{36} \mathrm{Id}$.

${ }^{37}$ Id at 91 (prepared statement of the American Federation of State, County and Municipal Employees).

${ }^{38} \mathrm{Id}$. 
Although Congress heard these views expressed in the hearings on the PRWORA, it did not specifically respond to them. Just as the text of the PRWORA does not answer the question of whether the FLSA applies to workfare participants, neither does the legislative history.

\section{The Department of Labor's position.}

Despite the ambiguity of the PRWORA, the DOL takes the position that the FLSA's minimum wage requirements apply to those welfare recipients who are "employees" under the FLSA's broad definition. ${ }^{39}$ In the DOL's opinion, welfare recipients "would probably be considered employees in many, if not most, of the work activities described" in the PRWORA. ${ }^{40}$ The DOL also takes the position that an individual in training is not an employee and therefore is not entitled to the minimum wage. ${ }^{41}$

Although the DOL favors applying the FLSA to workfare participants, the agency's interpretation should not be accepted as determinative of the issue. ${ }^{42}$ First, the DOL does not have administrative or enforcement responsibilities for the majority of TANF funding. ${ }^{43}$ And HHS, which does have enforcement respon-

${ }^{39}$ DOL, How Workplace Laws Apply to Welfare Recipients (cited in note 18) ("Federal employment laws, such as the Fair Labor Standards Act (FLSA) . . apply to welfare recipients as they apply to other workers.").

${ }^{40} \mathrm{Id}$.

11 The DOL lists the following criteria to help determine whether an individual is a trainee, and thus outside of the FLSA's coverage: (1) Training is similar to that given in a vocational school; (2) Training is for the benefit of the trainees; (3) Trainees do not displace regular employees; (4) Employers derive no immediate advantage from trainees' activities; (5) Trainees are not entitled to a job after training is completed; and (6) Employers and trainees understand that the trainee is not paid. Id.

${ }^{12}$ Professor Diller argues that the DOL's policy statement will not resolve the issue of whether workfare workers may be considered employees for purposes of federal labor laws, and he states that "[u]ltimately resolution [of this issue] will depend on the definition of terms such as 'employee' or 'wage' used in each of the ... federal laws establishing these protections." Diller, 9 Stan L \& Pol Rev at 27 (cited in note 12).

43 The DOL has administrative and enforcement responsibility for the Welfare-toWork ("WtW") grants that were authorized and created by the Balanced Budget Act of 1997. See Pub L No 105-33, 111 Stat 251, 577-93 (1997) (amending Title IV, Part A of the Social Security Act). Although the WtW program is coordinated with the closely related TANF program administered by HHS, WtW is administered by the DOL. See DOL, ETA, Welfare-to-Work Grants, 62 Fed Reg at 61588 (cited in note 28). The WtW plans are considered to be an "addendum" to larger state TANF plans. See Balanced Budget Act of 1997 $\S 5001$ (a)(5)(A)(ii)(I), 111 Stat at 578; DOL, ETA, Welfare-to-Work Grants, 62 Fed Reg at 61589.

While the funding provided by WtW "should occur within the larger framework of the TANF program in each State," the purposes of the WtW funds are distinct from those of the TANF program. See DOL, ETA, Welfare-to-Work Grants, 62 Fed Reg at 61588 . WtW funds are targeted specifically at hard-to-employ welfare recipients in high poverty areas who need assistance moving into unsubsidized employment. See id. The WtW program 
sibilities for TANF programs, has issued no policy statements or proposed rules regarding the applicability of the FLSA or other employment laws to TANF. In addition, it is not clear if the DOL's policy statement is owed much deference, as it is conclusory in nature and was not issued pursuant to the Administrative Procedure Act's notice and comment provisions. ${ }^{44}$

While the DOL's position that the FLSA applies to workfare is not authoritative, it serves as further evidence that application of the FLSA to workfare participants is reasonable. The DOL memo also accords with the approach taken by courts in other contexts ${ }^{45}$ in that it does not argue that minimum wage laws apply categorically to workfare participants, but instead argues that only certain workfare programs such as vocational education, job search assistance, and secondary school attendance are exempt from the FLSA's broad coverage. ${ }^{46}$

will receive $\$ 2.2$ billion to be allocated to states over two years based on their populations of poor people and adult recipients of TANF; the DOL will be allocated another $\$ 711.5$ million to award to local communities that will compete for these funds based on the creativity and sustainability of their strategies to attain quality employment for welfare recipients. See ETA Press Release, Labor Secretary Herman Announces First States to Share in \$2.2 Billion of Welfare-to-Work Grants (Jan 29, 1998), available online at <http://www. dol.gov/dol/opa/public/media/press/eta/eta98033.html (visited Sept 26, 1998). TANF, on the other hand, is slated to receive an estimated $\$ 16.4$ billion for each fiscal year until 2003. See HHS, Comparison of Prior Law (cited in note 22).

" Courts are split over whether the deference owed to agency interpretations of law, as set out in Cheuron USA, Inc $v$ Natural Resources Defense Council, Inc, 467 US 837, 84445 (1984), applies to interpretive rules or policy statements, as opposed to those rules published according to Administrative Procedure Act ("APA") rule-making procedures, 5 USC $\S 553$ (1994). Some courts have held, citing the pre-Cheuron case of Skidmore $v$ Swift $\&$ Co, 323 US 134, 139-40 (1944), that a nonlegislative agency interpretation of a statute (that is, an interpretation not subject to notice and comment procedures) should be afforded less deference than a rule established according to the APA's formal procedures. See, for example, Sicard $v$ City of Sioux City, 950 F Supp 1420, 1433-35 (N D Iowa 1996) (refusing to apply Chevron deference to a nonlegislative rule and summarizing caselaw in favor of this position), citing Skidmore, 323 US at 140. However, other courts have reasoned that such pronouncements should nonetheless be afforded full Chevron deference, stating that the Supreme Court has overruled Skidmore sub silentio. See, for example, Elizabeth Blackwell Health Center for Women v Knoll, 61 F3d 170, 182 (3d Cir 1995) (holding that the agency's construction of the statute "is accorded considerable weight under principles announced in Chevron"), cert denied, 516 US 1093 (1996): While the Supreme Court has held that nonlegislative interpretive rules are entitled to some deference, it has not yet decided whether full Cheuron deference applies. See Reno $v$ Koray, 515 US 50,61 (1995) (holding that an internal agency guideline, like an interpretive rule that does not require notice and comment, is entitled to some deference because it is a permissible construction of the statute).

is See Parts III.A.1 and III.A.3 for discussion of prison labor and volunteers and trainees, where even under the "whole activity" approach, courts do not categorically deny FLSA coverage without looking to see if the FLSA's purposes are implicated.

${ }^{45}$ See DOL, How Workplace Laws Apply to Welfare Recipients (cited in note 18). 
In sum, neither the text of the PRWORA nor its legislative history answers definitively whether Congress intended FLSA minimum wage protections to apply to workfare participants. The DOL's position, while not authoritative, is similar to courts' caseby-case analyses in other FLSA contexts, which the next two Parts illustrate are superior to a categorical denial of minimum wage protection.

\section{THE FATR LABOR STANDARDS ACT AND THE "ECONOMIC REALITIES" TEST}

This Part examines the text of the FLSA and judicial interpretations of its applicability. It then analyzes the doctrine prescribed by the Supreme Court to determine the applicability of the FLSA-the "economic realities" test-as interpreted by the circuit courts.

A. The FLSA's Broad Remedial Purposes and Rejection of Common Law Definitions of "Employee"

The FLSA provides that "[e]very employer shall pay to each of his employees ... engaged in commerce" the statutory minimum wage. ${ }^{47}$ Unfortunately, the FLSA's definitions of "employee" and "employer" are circular and provide little guidance to courts trying to interpret them. The FLSA defines the term "employ" as "to suffer or permit to work." An "employee" is defined as "any individual employed by an employer, ${ }^{39}$ and an "employer" is defined as "any person acting directly or indirectly in the interest of an employer in relation to an employee. ${ }^{n 50}$

Although the FLSA's text does not provide much guidance for determining which workers qualify as "employees" entitled to the minimum wage, the Supreme Court, noting that the FLSA was concerned with correcting broad economic evils unknown at common law, has rejected the application of common law conceptions of "employee" in the FLSA context. ${ }^{51}$ Therefore, rather than rely on common law definitions, the lower courts have focused on the broad definitions and remedial purposes of the FLSA to interpret the term. ${ }^{52}$

${ }^{47} 29$ USC $\S 206(a)$.

${ }^{43}$ Id § 203(g).

${ }^{49}$ Id $\S 203(\mathrm{e})(1)$.

${ }^{\text {so }}$ Id § 203(d).

${ }^{51}$ Rutherford Food Corp v McComb, 331 US 722, 726-27 (1947) (holding that the FLSA applied to meat boners who would not necessarily have been considered employees prior to the Act).

${ }^{52}$ See, for example, Dunlop v Carriage Carpet Co, 548 F2d 139, 143-44 (6th Cir 1977) 
The FLSA was aimed at correcting two types of mischief. First, it was designed to correct "labor conditions detrimental to the maintenance of the minimum standard of living necessary for health, efficiency, and general well-being of workers. ${ }^{353}$ The legislative history of the FLSA indicates "that the prime purpose of the legislation was to aid the unprotected, unorganized and lowest paid of the nation's working population; that is, those employees who lacked sufficient bargaining power to secure for themselves a minimum subsistence wage..154

Second, the FLSA concerned itself with ensuring fair competition not only among employers and employees, but within the marketplace in general. Congress did not wish to allow some employers to pay a subminimum wage and thereby gain a competitive advantage over other companies, thus "interfer[ing] with the orderly and fair marketing of goods in commerce." ${ }^{.55}$

As a result of these broad remedial goals underlying the FLSA, some courts have stated that the legislative history of the FLSA contains "the broadest definition [of employee] that has ever been included in any one act. ${ }^{756}$ This broad definition and the underlying goals should therefore factor into courts' decisions regarding whether the statute applies to workfare participants. Moreover, denying coverage to workfare participants under the broadest definition of "employee" would seem to preclude application of many other federal labor laws to workfare participants. Thus, courts should consider the consequences of such a decision.

("The Fair Labor Standards Act of 1938 was enacted by Congress to be a broadly remedial and humanitarian statute," and "courts have construed the Act's definitions liberally to effectuate the broad policies and intentions of Congress."); Johns, 57 F3d at 1557 ("The definition 'suffer or permit to work' was intended to make the scope of employee coverage under the FLSA very broad.").

${ }^{83} 29$ USC \& 202(a). See also Dunlop, 548 F2d at 143 (quoting same provision); Mitchell $v$ Robert DeMario Jewelry, Inc, 361 US 288, 292 (1960) ("The central aim of the [FLSA] was to achieve, in those industries within its scope, certain minimum labor standards.").

st Brooklyn Savings Bank v O'Neil, 324 US 697, 707 n 18 (1945), citing legislative history in 81 Cong Rec S 7652, 7672, 7885 (July 27, 1937); 82 Cong Rec H 1386, 1395 (Dec 13, 1937); 82 Cong Rec H 1491, 1505, 1507 (Dec 14, 1937); 83 Cong Rec H 7283, 7298 (May 23, 1938); 83 Cong Rec H 9260, 9265 (June 14, 1938).

${ }^{\infty} 29$ USC $\S 202(a)(5)$. Other enumerated problems identified in Section 202(a) include any labor condition that:

(1) causes commerce and the channels and instrumentalities of commerce to be used to spread and perpetuate such labor conditions among the workers of the several States; (2) burdens commerce and the free flow of goods in commerce; (3) constitutes an unfair method of competition in commerce; (4) leads to labor disputes burdening and obstructing commerce and the free flow of goods in commerce.

${ }^{56}$ Dunlop, 548 F2d at 143, quoting United States $v$ Rosenwasser, 323 US 360, 363 n 3 (1945), quoting statement of Senator (later Justice) Hugo Black; Johns, 57 F3d at 1557, quoting the same statement. 
Consistent with its interpretation of the broad remedial goals of the FLSA, the Supreme Court has held that any exemptions from the statute should be narrowly construed. ${ }^{57}$ Because the FLSA is a broadly remedial and humanitarian statute that defines "employee" and "employer" very generally while defining its exemptions with specificity, ${ }^{58}$ the legislative intent to provide coverage for a particular class of workers may be inferred from the fact that the group is not included in the exemptions. ${ }^{59}$

Workfare participants are not explicitly excluded from the FLSA. While this omission suggests that they should be granted FLSA minimum wage coverage, it is not dispositive. Often Congress fails to exempt or specify a certain group not because it intended to extend coverage to those workers, but simply because it did not anticipate the situation at the time of the legislation's passage. ${ }^{60}$ As the TANF program did not exist in 1938, it is impossible to ascribe any actual intent regarding workfare participants to the Congress that passed the FLSA.

\section{B. The Supreme Court's "Economic Realities" Test and Application of the Bonnette Approach}

In Goldberg $v$ Whitaker House Cooperative, Inc, ${ }^{61}$ the Supreme Court held that "economic reality" should be the general test of "employment" within the meaning of the FLSA. ${ }^{62}$ The Court's failure to specify which particular aspects of "economic reality" might lead to a finding of employment under the FLSA has resulted in the development of different approaches to defining "economic reality." The Ninth Circuit in Bonnette $v$ California

\footnotetext{
${ }^{67}$ A.H. Phillips, Inc $v$ Walling, 324 US 490, 493 (1945) ("Any exemption from [the FLSA] must therefore be narrowly construed, giving due regard to the plain meaning of statutory language and the intent of Congress.").

${ }^{58} 29$ USC \& 203(e)(2)-(4) provides several exceptions to the term "employee," which generally "means any individual employed by an employer." Id § 203(e)(1).

${ }^{59}$ The Supreme Court has expressed this attitude generally in United States $v$ Silk, 331 US 704, 711-12 (1947) ("The very specificity of the exemptions, however, and the generality of the employment definitions indicates that the terms 'employment' and 'employee,' are to be construed to accomplish the purposes of the [FLSA]."). In Watson $v$ Graves, 909 F2d 1549, 1554 (5th Cir 1990), the Fifth Circuit also found this argument to have some merit, noting that prison inmates were "not one of the groups Congress expressly excluded from coverage by FLSA."

${ }^{\infty}$ Consider James K. Haslam, Prison Labor Under State Direction: Do Inmates Have the Right to FLSA Coverage and Minimum Wage?, 1994 BYU L Rev 369, 388 (1994), which argues that "Congress would only exempt those naturally considered to be employees in the first instance."

${ }^{61} 366$ US 28 (1961).

22 Id at 33 (holding that members of a cooperative were also employees for purposes of the FLSA because of the relationship between the members and management).
} 
Health and Welfare Agency ${ }^{63}$ announced a four factor approach "based on 'a consideration of the total employment situation and the economic realities of the work relationship." While some circuits have adopted different approaches, which are discussed in the next Part, Bonnette is now widely accepted as the proper approach to the Supreme Court's "economic realities" test. ${ }^{65}$ The Bonnette factors include whether the employer: (1) had the power to hire and fire the employees, (2) supervised and controlled employee work schedules or conditions of employment, (3) determined the rate and method of payment, and (4) maintained employment records. ${ }^{66}$

While the four factor approach was first applied in Bonnette as a guide to which agencies qualified as "employers," it has been extended to many kinds of employment relationships, including nontraditional employment situations such as prison labor. Thus, it may logically be extended to apply to workfare, another form of nontraditional employment.

\section{Prison workers.}

In Watson $v$ Graves, ${ }^{67}$ the Fifth Circuit applied the four Bonnette factors and held that inmates who had worked for private parties outside of the prison under a work release program were FLSA "employees." ${ }^{\text {"In }}$ In applying the Bonnette factors, the court noted that the FLSA's goals of "eliminat[ing] unfair competition among employers competing for business in the market and among workers looking for jobs" should be taken into account in the "true economic reality of inmate labor outside of the prison." Thus, the fact that the employers did not provide overtime, social security, or other employee benefits to the prison inmates was at

\footnotetext{
\% 704 F2d 1465 (9th Cir 1983).

c4 Id at 1470, quoting Bonnette $v$ California Health and Welfare Agency, 525 F Supp 128,135 (N D Cal 1981).

${ }^{65}$ See, for example, Watson, 909 F2d at 1554-56 (applying the four factor test articulated in Bonnette); Carter v Dutchess Community College, 735 F2d 8, 12 (2d Cir 1984) (same); George v Badger State Industries, 827 F Supp 584, 587 (W D Wis 1993) (noting that "[i]n most cases, courts apply the four-factor test established in Bonnette" to determine whether an employer-employee relationship is established).

${ }^{66}$ Bonnette, 704 F2d at 1470.

${ }^{67} 909$ F2d 1549 (5th Cir 1990).

${ }^{68}$ Id at 1556. The Ninth Circuit has also applied the Bonnette test in the prisonworker context to hold that prisoners who worked for a state entity making products for sale outside the prison were "employees" under the FLSA. See Hale v Arizona, 967 F2d 1356, 1362-64 (9th $\mathrm{Cir} 1992)$.

${ }^{69}$ Watson, 909 F2d at 1554.
} 
the heart of the mischief the FLSA was intended to correct-unfair competition between employers and employees. ${ }^{70}$

2. Workfare participants.

Work required under programs such as TANF and its predecessor AFDC has usually meant workfare. ${ }^{71}$ Under AFDC, some states treated workfare as merely one component of a broader welfare-to-work program, which also included education, job training, or job search assistance. ${ }^{72}$ In other states, participants who failed to find jobs through other activities were assigned to workfare jobs, which often required them to perform community service, usually for government agencies or nonprofit organizations. ${ }^{73}$ These positions were typically nonpaying. ${ }^{74}$

In contrast, government-sponsored on-the-job training programs required employers to pay employees regular wages; in turn, the employer typically received a subsidy from the state equal to about one half of the employee's wages. ${ }^{75}$ TANF, however, treats many more options as qualified work activities, ${ }^{76}$ therefore, individual states may continue to utilize traditional unpaid or underpaid workfare jobs to satisfy minimum participation rates under TANF.

Under the four part approach to the "economic realities" test, however, at least some of these workfare participants qualify as "employees" guaranteed the statutory minimum wage. Applying the first Bonnette factor, even if the government agency or nonprofit organization does not have the formal power to hire and fire these workers, they often may have the de facto power to do so. In Watson, the court reasoned that because the work-release contractor could request or reject particular inmates, it did not matter that the warden could technically overrule this decision because it would serve de facto as the ultimate decision. ${ }^{77}$ With

${ }^{70}$ Id at 1555.

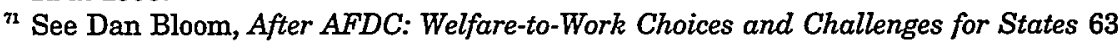
(Manpower Demonstration Research Corp 1997) ('Since 1981, mandatory work in the AFDC program has usually meant workfare.").

${ }^{72}$ See id.

${ }^{73}$ See id.

" See id. See also Daniel Friedlander and Gary Burtless, Five Years After: The LongTerm Effects of Welfare-to-Work Programs 4 (Russell Sage 1995) (describing how “[e]nrollees who failed to find a job could be assigned to three-month unpaid work positions in public or nonprofit institutions").

${ }^{75}$ Bloom, After AFDC at 69 (cited in note 71).

${ }^{76}$ See note 22 and accompanying text.

" 909 F2d at 1555. Also, the Bonnette court noted that this factor could be satisfied not only by a technical ability to hire and fire, but also where the employer's "power over the employment relationship by virtue of their control over the purse strings was substan- 
workfare programs, it is reasonable to think that the agency or organization could have substantial input as to which participants it will take in or retain.

The second Bonnette factor, "supervision and control," is easily satisfied in most workfare situations. By assigning participants to mandatory work, it seems to follow that they will have to comply with reasonable work requirements and supervision in order to remain eligible for welfare benefits.

Whether the third and fourth factors of the Bonnette approach, employer determination of the rate and method of payment and maintenance of employment records, are satisfied depends on the specifics of the individual employment situation. For instance, states may confine the role of their social service agencies to finding employment for participants, and they may allow the government agency or nonprofit organization to determine how much it will pay participants for particular jobs. Also, once the welfare recipient is put to work, there are several methods through which the putative "employer" may keep a record of the "employment." Thus, it is hard to say categorically that workfare participants either fail or satisfy the third and fourth factors.

The application of the Bonnette approach to the Supreme Court's "economic realities" test in the workfare context will require courts to analyze on a case-by-case basis the workfare employment relationship "in light of the policies behind FLSA." "78 Where the broad goals of the FLSA are implicated, such as where there is a risk of unfair competition within the marketplace, courts may conclude that participants are entitled to the minimum wage. The next Part discusses courts' departures from the Bonnette approach, but concludes that these alternative approaches also should lead to a case-by-case analysis in the workfare context.

\section{THE "WHOLE ACTIVTTY" APPROACH AND JOHNS V STEWART}

Some courts have refused to employ the Bonnette factors in certain nontraditional employment contexts. When a court opts for another approach to determine whether a worker qualifies as a FLSA "employee," that approach is often less favorable to those seeking the protection of the labor statute. This Part argues, however, that even an approach that considers the "whole activ-

\footnotetext{
tial." 704 F2d at 1470.

${ }^{73}$ Watson, 909 F2d at 1555 (arguing that these factors are "superficial facts" and that application of the FLSA should not be precluded without analysis of the policies behind the FLSA). For discussion of how these policies apply in the workfare context, see Part IV.
} 
ity" or the "totality of the circumstances" should lead to a case-bycase analysis in which workfare participants will often qualify as "employees."

\section{A. The "Whole Activity" or "Totality of the \\ Circumstances" Approach}

Bonnette established a four part approach to "economic realities" that is often applied with a thumb on the employee's side of the scales. Nonetheless, there is at least some support in the Bonnette opinion itself for an alternative approach. The Ninth Circuit noted that while the factors provided "a useful framework for analysis in this case, ... [t] the ultimate determination must be based 'upon the circumstances of the whole activity."'79 Building on such language in Bonnette and in Rutherford Food Corp $v$ $M c C o m b,{ }^{80}$ some courts have applied the "whole activity" or "totality of the circumstances" approach to "economic realities" in certain nontraditional work contexts. Courts adopting this approach reject the application of the Bonnette factors and instead determine whether in "economic reality" workers are "employees" by analyzing the "situation as a whole" or "in its entirety."

\section{Prison workers.}

Courts that adopt the "whole activity" approach in the prison worker context generally hold that prison inmates who work for their custodians are not "employees," but some suggest that inmates who work for nonprison employers may be considered employees. A Fifth Circuit case, Reimonenq $v$ Foti ${ }^{82}$ held that the four Bonnette factors did not apply in the jailer-inmate context because the factors are based on the amount of control the employer has over the employee-control that in the prison context is nearly absolute. ${ }^{83}$ Instead, the Fifth Circuit held that a

\footnotetext{
${ }^{79}$ Bonnette, 704 F2d at 1470 (emphasis added), quoting Rutherford Food Corp $v$ McComb, 331 US 722, 730 (1947).

${ }^{80} 331$ US 722, 730 (1947) ("[D]etermination of the relationship does not depend on such isolated factors but rather upon the circumstances of the whole activity.").

${ }^{81}$ Villarreal $v$ Woodham, 113 F3d 202, 206-07 (11th Cir 1997) (concluding that prison workers are not employees under the FLSA).

62 72 F3d 472 (5th Cir 1996).

${ }^{3}$ Id at 475. See also Danneskjold v Hausrath, 82 F3d 37, 42-43 (2d Cir 1996) (declining to apply the Bonnette four factor test in the context of prison labor, and summarizing caselaw that "has essentially read Bonnette, but not necessarily the economic reality test, out of the determination of whether a particular prisoner's labor is subject to the FLSA"); Vanskike $v$ Peters, 974 F2d 806, 810 (7th Cir 1992) ("[T] here is obviously enough control over the prisoner; the problematic point is that there is too much control to classify the relationship as one of employment.").
} 
court should analyze the "practical realities of the custodian/convict relationship." 84 Noting that the prison work release programs in which the inmates participated operated for the benefit of the inmates, the court adopted a categorical rule that prison custodians are not employers of inmates. The "economic reality" may be that prison-workers are not "employees" of their custodians; rather, they work as a result of their incarceration. ${ }^{85}$

Even the "totality of the circumstances" approach, however, may not foreclose application of the FLSA to prisoners. In Henthorn $v$ Department of $N a v y,{ }^{86}$ the D.C. Circuit refused to apply the four factor approach to "economic realities" and held that prison inmates who worked for prison officials were not "employees," reasoning that these inmates were legally compelled to work. ${ }^{87}$ But the court noted that in cases where the prisoner has freely and voluntarily contracted to sell his labor to a nonprison employer, the court should apply the four Bonnette factors. ${ }^{88}$ Thus, for the Henthorn court, the key factor in determining whether or not to use the Bonnette approach was the extent to which the work was compelled or forced upon the worker. ${ }^{89}$

Another court that rejected application of the Bonnette factors in the prison context has emphasized that the FLSA may apply to nonprison employers where its goals of preventing unfair competition are implicated..$^{90}$ That court was concerned that companies able to hire prison labor at sub-FLSA wages may have an unfair competitive advantage over other companies employing private labor. ${ }^{91}$ Thus, even though a court may refuse to apply the four factor approach to "economic reality," it may nonetheless hold that the FLSA's minimum wage applies.

\& Reimonenq, 72 F3d at 476.

${ }^{85}$ Vanskike, 974 F2d at 810.

${ }^{86} 29$ F3d 682 (DC Cir 1994).

${ }^{87} \mathrm{Id}$ at $686-87$.

Id at 686.

Id at 686-87 ('[W]here the inmate's labor is compelled . . . the prisoner is barred from asserting a claim under the FLSA, since he is definitively not an 'employee.").

"Danneskjold, 82 F3d at 44 (noting that unfair competition "is not a wholly unrealistic concern" and concluding that "[w]here a prisoner's work for a private employer . . . would tend to undermine the FLSA wage scale, ... the FLSA applies"). Compare Alexander B. Wellen, Prisoners and the FLSA: Can the American Taxpayer Afford Extending Prison Inmates the Federal Minimum Wage?, 67 Temple L Rev 295, 333 (1994) (arguing that the economic burden of paying prisoners the minimum wage "significantly outweighs" any costs of prison goods infiltrating the private sector).

${ }^{91}$ Danneskjold, 82 F3d at 44. 
2. Workfare participants.

Are welfare recipients compelled to participate in workfare programs? The reasoning of the courts following the "whole activity" approach to economic reality in the prison context supports the conclusion that workfare participants are not compelled to work. These courts distinguish between inmates who work for their custodians, who are not covered by the FLSA, and inmates who work for outside employers, who may be covered by the FLSA. Workfare participants certainly do not face the same degree of compulsion as inmates who work for their custodians, as their employment results from their incarceration. Workfare participants' compulsion is more analogous to that of prison workers who choose to work for nonprison employers. Both workfare participants and prison workers who work for private employers retain some control over the terms and conditions of their employment, distinguishing them from inmates who work for their custodians. The logic of these cases suggests that because workfare participants are not compelled to work, the Bonnette factors should be applied to determine whether the participants are "employees."

Even courts that do not apply the Bonnette factors to workfare participants should consider whether the broad remedial goals of the FLSA are implicated by the participants' work. Allowing companies to pay workfare participants sub-FLSA wages may have detrimental competitive effects. If participants are placed in for-profit industries or nonprofit organizations that engage heavily in commerce, ${ }^{92}$ those companies fortunate enough to have this cheap labor supply will be able to run their businesses with lower salary expenses than their competition. ${ }^{93}$ This argues

${ }^{92}$ See Leda E. Dunn, "Protection" of Volunteers Under the Federal Employment Law: Discouraging Voluntarism?, 61 Fordham L Rev 451, 464-65 (1992) (arguing that nonprofit organizations that treat their "volunteers" like regular employees and that engage heavily in commerce should be subject to the FLSA's minimum wage provisions in keeping with the intent of Congress).

${ }^{\infty}$ See text accompanying notes $142-44$ for an example of a recent case employing this logic.

Critics may respond that lower salary expenses only reflect the fact that these workfare participants are, on average, less productive than other workers, and that it therefore makes sense that they should be paid less. Thus, they could argue, this is not truly a windfall to employers. But the reality is that most workfare participants are working in jobs that require little training and where productivity does not make a big difference. Indeed, this reality about workfare has led to a great deal of criticism about the nature of these jobs. See, for example, Derrick Z. Jackson, Lazy Lies about Welfare, Boston Globe A23 (Apr 29, 1998) ("There is clear evidence that New York's 33,000 workfare participants are nothing but cheap labor."); Bernice Powell Jackson, The Emperor's New Clothes: After Welfare Reform, NY Beacon 21 (May 27, 1998) (warning that "workfare participants have 
against any categorical exemption for workfare and points to the need for a case-by-case analysis of the market effects and the implications for the FLSA's goal to eliminate unfair competition.

\section{Other contexts-volunteers and trainees.}

While the FLSA exempts "any individual who volunteers to perform services for a public agency" from the minimum wage, ${ }^{94}$ workfare participants do not fall within this exemption. Courts should consider the individual's subjective motivation to work when determining whether a worker is a volunteer or an employee. In Rodriguez $v$ Township of Holiday Lakes, ${ }^{95}$ for example, a nonpaid patrol officer of the township brought an action against the municipality for violation of the minimum wage and overtime provisions of the FLSA. The district court refused to apply the "economic realities" test to distinguish an employee from a volunteer because the situation was one in which no payments at all were made between the parties. ${ }^{96}$ The court found the fact that the officer was motivated to work not "for civic, charitable, or humanitarian reasons, ${ }^{p 7}$ but solely out of self-interest, weighed against finding that the officer was a volunteer.

Because subjective motivation is a factor in determining an individual's volunteer status, workfare participants should not be classified as volunteers. Welfare recipients may be civic-minded and charitable, but they work because TANF requires them to do so in order to continue receiving benefits. Any label placed on their employment position does not change that reality.

A more difficult issue is whether workfare participants are "trainees" rather than employees. One court that refused to extend FLSA coverage to trainees emphasized the fact that the training was for the benefit of the trainees, and that the program was "comparable to vocational school" in that it taught "skills that are fungible within the industry," regardless of whether the program emphasized the employer's particular policies. ${ }^{98}$ But courts have found trainees to be employees when they displace

proven to be an irresistible, cheap labor force to provide falling city services"); Leonard Greene, Protesters Decry Rudy's Workfare, Newsday A49 (Aug 23, 1998) (noting that critics of the city's workfare program argue that it is "little more than a source of cheap labor for the city, a work pool that undercuts legitimate union jobs"). There is a legitimate concern that employers are obtaining a windfall by tapping into this cheap source of labor.

of 29 USC $\S 203(e)(4)(A)$.

${ }^{2} 866$ F Supp 1012 (S D Tex 1994).

${ }^{9}$ Id at 1020 .

${ }^{97}$ Id at 1019, quoting 29 CFR $\$ 553.101$ (a).

${ }^{9}$ Reich v Parker Fire Protection District, 992 F2d 1023, 1028 (10th Cir 1993). 
current employees, ${ }^{99}$ when they assume the duties of the position, ${ }^{100}$ or when "training consists merely of supervising trainees as they carry out employees' duties. ${ }^{\text {101 }}$

Some workfare programs may carry the indicia of true training. TANF permits participation in up to twelve months of vocational school, ${ }^{102}$ and it is hard to argue that this is not training when there is no "employer" present. With other workfare programs, however, such as on-the-job training or subsidized employment, factors that qualify these workers as "employees" seem to be present. That is, the workfare participants are likely displacing other employees, and often their "training" is merely acclimation to a supervised workplace. Certainly, the skills they learn will be transferable within certain industries or even in the labor market in general, but this is true of any job-employees learn new skills on the job that will help them in their future careers. Thus, most workfare programs are not merely training ${ }^{103}$ but instead are true employment properly subject to the FLSA's minimum wage provisions.

\section{B. Workfare Participants Categorically Not Employees Under Johns $v$ Stewart}

The only circuit ${ }^{104}$ to have addressed the applicability of the FLSA to workfare participants has held that they are not employees for purposes of the FLSA. In Johns, the Tenth Circuit considered Utah's Work Experience and Training ("WEAT") proj-

${ }^{99}$ Marshall v Baptist Hospital, Inc, 473 F Supp 465, 473-74 (M D Tenn 1979) (holding $\mathrm{x}$-ray technician trainees to be employees because they performed all of their duties "in a fashion that displaced regular employees"), revd on other grounds, 668 F2d 234 (6th Cir 1981).

${ }^{100}$ Bailey $v$ Pilots' Association for the Bay and River Delaware, 406 F Supp 1302, 1307 (E D Pa 1976) (concluding that an apprentice river pilot was an employee because he performed tasks necessary to the functioning of the pilot boat).

${ }^{101}$ Reich, 992 F2d at 1028 (describing situation in which courts have found trainees to be employees).

${ }^{102}$ See note 22.

${ }^{103}$ Because the PRWORA provides that participation in education programs or even job skills training does not count toward the first twenty hours per week of work activity, workfare participants will likely spend most of their time in what this Comment considers "employment." See PRWORA § 407(c)(1), 110 Stat at 2131. See also Diller, 9 Stan L \& Pol Rev at 25 (cited in note 12) (arguing that the 'PRWORA reflects the view that it is inappropriate to permit welfare recipients to remain out of the workforce while they gain skills or training to improve their long-term employability").

${ }^{104}$ Previously the Tenth Circuit denied that workfare participants were "employees" under the Food Stamp Act of 1964, 7 USC \& 2011 (1970); however, the Act did not involve a similar definition of "employee" as that found in the FLSA, and the court did not apply any court-created tests of employment. See Klaips $v$ Bergland, 715 F2d 477, 483 (10th Cir 1983). 
ect, which was part of the Financial Assistance General Assistance/Self-Sufficiency Program ("GA"). ${ }^{105}$ GA-WEAT required recipients to participate in a minimum of ninety-six hours per month of community work, adult education, or skills training activities. ${ }^{106}$

The state assigned Johns to perform maintenance and painting duties at a local corporation. ${ }^{107}$ After sustaining injuries on the job, Johns brought a class action suit against the program, alleging that the state had violated Section 206 of the FLSA by paying the participants less than the minimum wage for the hours they participated in GA-WEAT and related programs. ${ }^{108}$ In addressing the applicability of the FLSA to the class of participants, the court first concluded that the Utah Department of Human Services, as the public agency administering the GAWEAT programs, qualified as an "employer" for purposes of the FLSA. ${ }^{109}$ Thus, the key determination for purposes of the FLSA was whether the plaintiffs qualified as "employees."110 The court concluded they did not. While it noted that the FLSA contained a broad definition of "employ" and that the term "employee" was given the "broadest definition that has ever been included in any one act," it also noted the Supreme Court's statement in Tony and Susan Alamo Foundation $v$ Secretary of Labor ${ }^{111}$ that the definition "does have its limits." the Bonnette four factor approach was not applicable outside of the employee/independent contractor context. ${ }^{113}$

\footnotetext{
${ }^{106}$ Utah Admin Code § R986-218 (1996 \& Supp 1997).

${ }^{106}$ Johns, 57 F3d at 1549.

${ }^{107}$ Id at 1550-51.

${ }^{108}$ Id at 1551.

${ }^{109}$ Id at 1557 . The court held that the definition of "employer," which is "any person acting directly or indirectly in the interest of an employer in relation to an employee and includes a public agency, included any agency of a state. Id.

${ }^{110} \mathrm{Id}$.

"11 471 US 290 (1985).

${ }^{112}$ Johns, 57 F3d at 1557, quoting Alamo Foundation, 471 US at 295. The Johns court stated further that "although some persons are literally 'suffer[ed] or permit[ted] to work,' they do not qualify as 'employees' for purposes of the FLSA." Johns, 57 F3d at 1557.

${ }^{113}$ Johns, 57 F3d at 1559 n 21. Actually, the Tenth Circuit has not adopted the four factor approach, but instead applies a five factor inquiry taken from Doty $v$ Elias, 733 F2d 720, 722-23 (10th Cir 1984). However, this is not significant here because the Johns court would refuse to apply either test outside of the independent contractor context. See Johns, 57 F3d at $1559 \mathrm{n} 21$. The court also refused to apply a six factor test that applies to issues of employee versus trainee status. See id. See also Reich, 992 F2d at 1025-27.

In refusing to apply these employment tests, the court noted that they are merely helpful analytical guides, "not rigid criteria which must be mechanically applied to each case." Johns, 57 F3d at 1559 n 21, citing Bonnette, 704 F2d at 1470. See also Reich, 992 F2d at 1027.
} 
In doing so, the court relied on an analogy to another Tenth Circuit case involving student resident hall assistants ("RAs"), in which the court held that the student workers were not "employees" for purposes of the FLSA. In Marshall $v$ Regis Educational Corp ${ }^{114}$ the court reasoned that under the "totality of the circumstances" and in light of the "circumstances of the whole activity," the primary relationship was one of education, not of employment. ${ }^{115}$ Specifically, the Marshall court held that while the college might derive some economic value from the RA program, the assistance to the administration of the residence hall was "only one circumstance in the whole activity of the college program."116 Johns picked up on this language and concluded that narrowly focusing on the work component of the GA-WEAT and related programs "fails to take into consideration the circumstances of the whole activity."117

Finally, the court opined that a comparison to other state employees was inapposite. ${ }^{118}$ GA-WEAT participants did not go through a normal job application process and were not paid from the state payroll. Instead, they applied for public assistance and received financial assistance checks through a separate payment system. ${ }^{119}$ Also, state and federal taxes were withheld from state employees' paychecks, but were not withheld from GA-WEAT participants' benefits. ${ }^{120}$

Unfortunately, the Johns court incorrectly analyzed several important issues. First, the court's reliance on Alamo Foundation for the proposition that the FLSA's broad definition of "employee" is limited was misplaced. In Alamo Foundation, the Supreme Court held that associates of a religious foundation were employees, not volunteers. ${ }^{121}$ While the Court acknowledged that the broad statutory definition of "employee" has its limits, ${ }^{122}$ this dictum simply means that persons "who, without any express or implied compensation agreement, might work for their own advan-

${ }^{114} 666$ F2d 1324 (10th Cir 1981).

${ }^{115} \mathrm{Id}$ at 1327-28.

${ }^{116} \mathrm{Id}$ at 1328.

${ }^{117} 57$ F3d at 1558. The GA-WEAT and related programs also required that recipients "(1) meet a needs test; (2) be unemployable, marginally employable, or 60 years old or older ... ; (3) have no dependent children and be able to perform a work project ... ; and (4) agree to participate in adult education, training, skills development, and job search activities." Id.

${ }^{118}$ Id ("Indeed, GA-WEAT . . . participants are completely unlike state employees in every respect.").

${ }^{119}$ Id.

${ }^{120} \mathrm{Id}$.

${ }^{121} 471$ US at 302.

${ }^{122} \mathrm{Id}$ at 295. 
tage on the premises of another" are not "employees."123 But it is not at all clear that this description applies to all workfare participants. As noted earlier, workfare participants may be working not only for their own benefit, but also for the benefit of the employer. ${ }^{124}$ Thus, according to the Alamo Foundation Court, if the associates expected to receive employment benefits in exchange for their services, they would be "employees. ${ }^{1125}$ Like the approach taken in Rodriguez, ${ }^{126}$ this inquiry turns on the subjective motivations of the workfare participants.

Second, the exemption for student-workers in Marshall that the court relied on has not been universally applied by the courts. In Ivan $v$ Kent State University, ${ }^{127}$ the court held that a graduate student assistant was an "employee," that [the plaintiff] was a student does not negate her employee status." 129

Finally, in rejecting any comparison between GA-WEAT participants and other state employees, the Johns court did not discuss any of the FLSA's purposes-that is, elimination of unfair competition among employers and employees and lessening the distribution in commerce of goods produced under subnormal labor conditions. ${ }^{130}$ As discussed previously, workfare labor may have a substantial impact on the market and may be at the heart of the mischief the FLSA was intended to correct. ${ }^{131}$ These issues should have warranted at least some attention in the case.

In sum, Johns should be treated as an anomaly. Rather than considering the policy goals behind either the FLSA or PRWORA, the court relied on an analogy to RAs summarily to reject application of the minimum wage protections. There is no indication that participants in other workfare programs, even ones that bore all the indicia of true employment, would qualify as "employees" under this approach. Thus, the decision essentially amounts to a

${ }^{223}$ Id at 300.

${ }^{124}$ See Part III.A.2.

${ }^{125} 471$ US at 301.

${ }^{125}$ See text accompanying notes $95-97$.

127 863 F Supp 581 (N D Ohio 1994), affd without opinion, 92 F3d 1185 (6th Cir 1996).

${ }^{228}$ Id at 585-86. While this case involved the application of Title VII to a graduate student worker, courts have held that because the definitions of "employee" and "employer" are nearly identical under both Title VII and the FLSA, and because both statutes have broad remedial purposes, "cases construing the definitional provisions of one are persuasive authority when interpreting the others." Hyland $v$ New Haven Radiology Association, PC, 794 F2d 793, 796 (2d Cir 1986). See also Wheeler v Hurdman, 825 F2d 257, 263 (10th Cir 1987).

\footnotetext{
${ }^{129}$ Ivan, $863 \mathrm{~F}$ Supp at 585.

${ }^{130}$ See Part II.A.

${ }^{231}$ See Part III.A.2.
} 
categorical denial of FLSA coverage to this class of workers. Typically courts do not categorically deny that a class of workers can qualify as "employees" entitled to coverage under the FLSA. Instead, whether a court opts for the four factor approach to the "economic realities" test or for a "whole activity" approach, a caseby-case analysis is necessary to determine if the "economic reality" of the relationship is one of employment and if the circumstances are such that the broad remedial goals of the FLSA are implicated.

\section{FURTHER JUSTIFICATION FOR APPLICATION OF FLSA TO WORKFARE PARTICIPANTS}

In addition to the fact that many workfare programs are properly classified as employment relationships under the Supreme Court-created "economic realities" test and related doctrines, affording workfare participants minimum wage protection is a sound policy decision and is consistent with the goals of the FLSA.

\section{A. Applying the Minimum Wage to Workfare Participants Is} Consistent with the Broad Policy Goals of the FLSA

By enacting the FLSA, Congress intended both to achieve minimum labor standards and to ensure that employers would not take advantage of lower wages to dominate the marketplace. Applying the minimum wage to workfare furthers both of these goals: the lowest paid of the nation's workers can achieve a minimum standard of living, and the market is not disrupted by an influx of below-market labor costs.

1. Achieving minimum labor standards for the lowest paid of the nation's working population.

Denying minimum wage protection to workfare participants would fall short of guaranteeing them a minimum standard of living and would do nothing to help balance out the bargaining inequalities between employers and these workers. First, one commentator has argued persuasively that the welfare debate has erroneously focused on using the denial of benefits to influence recipients to go to work. She contends that welfare reform should instead focus on what she considers to be the central issue of welfare dependency-poverty. ${ }^{132}$ One of the main catalysts of

\footnotetext{
${ }^{132}$ Nichola L. Marshall, The Welfare Reform Act of 1996: Political Compromise or Panacea for Welfare Dependency?, 4 Georgetown J on Fighting Poverty 333, 336-37 (1997)
} 
the poverty problem is declining wage levels. ${ }^{133}$ Thus, simply requiring welfare recipients to go to work will not, at least in the short-term, solve the poverty problem if workfare participants will not be guaranteed even a minimum wage for their work. ${ }^{134}$

Welfare reform that does not guarantee that recipients will move into jobs paying above-poverty wages may be destined to fail. A commentator recently criticized the PRWORA's seemingly singular focus on participation rates and its failure to make "distinctions between successful placements and those likely to fail." 135 As this commentator noted: "Plagued by similar shortcomings, even the most successful welfare-to-work programs in the past have been mostly ineffectual." ${ }^{136}$ As wages are an integral part of the package of benefits welfare recipients receive, ensuring that these wages meet the statutory minimum level is essential to move recipients from dependency to independence.

Second, although there may be some chance of long-term success if the jobs do truly provide participants with good training and marketable skills, success still depends on building welfare recipients' self-esteem. Denying workfare participants equal treatment with other employees perpetuates and further embeds employers' (and employees') beliefs that these workers are inferior and less desirable. Professor Matthew Diller has noted that although "[w]orkfare proponents often speak or write glowingly of the dignity of work," workfare participants do not achieve this dignity because they "are still stigmatized as welfare recipients, a status perceived as a mark of social failure in society." ${ }^{\text {137 }}$ While Professor Diller uses this point to argue that education and training, not employment, should be the focus of any welfare re-

(noting that denial of benefits is not effective because "[w]elfare dependency is rooted in poverty, not in idleness or sloth").

${ }^{133}$ Id at $336-37,340$.

${ }^{24}$ Professor Diller makes this point about low wages in general. See Diller, 9 Stan L \& Pol Rev at 25-26 (cited in note 12) (noting that "the impact of these increased earnings is so minimal that most programs show little progress in moving recipients off welfare, let alone moving them out of poverty"). Thus, where the welfare recipient is moving to a job that pays below the minimum wage, it is even harder to see how the PRWORA will break the cycle of dependency.

${ }^{225}$ Deily, 12 Berkeley Women's $L J$ at 135 (cited in note 3), quoting The National Association of Child Advocates, Multi-State Children's Budget Watch Report 65 (1996).

${ }^{136}$ Deily, 12 Berkeley Women's L J at 135 (cited in note 3). Deily does note that workfare has generally provided an increase in family earnings, but that this increase is typically attributable to additional hours worked, not to increased wages. Id. See also Bloom, After AFDC at 41 (cited in note 71) (arguing that "welfare recipients who are pushed into the labor market too quickly typically obtain unstable, low-wage jobs and end up back on welfare").

${ }^{137}$ Diller, 9 Stan L \& Pol Rev at 28 (cited in note 12). 
form, ${ }^{138}$ one can just as forcefully argue that placing workfare participants on equal ground with other workers by paying them at least the minimum wage will go a long way toward restoring their dignity.

One likely response to the point that paying subminimum wages further embeds the belief that these workers are less desirable is that if the market wage for these workers is below the minimum wage, then the employers' beliefs must be right. That is, the workers really are less desirable. However, this argument misses the point. The FLSA was aimed at protecting "employees who lacked sufficient bargaining power to secure for themselves a minimum subsistence wage." ${ }^{\text {139 }}$ Because TANF requires welfare recipients to work in order to avoid losing benefits, participants in state workfare programs will seldom have much bargaining power to demand even the minimum wage. Indeed, their bargaining power is arguably weaker than that of most employees covered by the FLSA. Thus, requiring employers to pay a higher wage than they otherwise would responds to Congress' recognition that there is a large disparity in the two groups' bargaining positions.

A second answer to this criticism lies in the collective action problem that these workfare participants face. Professor Cass Sunstein argues that often regulation-in this case, a minimum wage law-is necessary to overcome a collective action problem that prevents citizens from producing outcomes that they "reflectively judge best but cannot obtain on their own."140 Here the collective action problem is exacerbated further by the lack of bargaining power noted above. Workfare participants left to bargain on their own will have no means of coordinating their efforts to ensure that they will not, as a group, accept wages below the minimum wage. Because they are all now required to work in order to continue receiving welfare benefits, they will be forced to accept whatever salary they can obtain rather than collaborating to demand the statutory minimum wage. The problem becomes even more acute when these welfare recipients are faced with a maximum amount of time they can engage in job search activities. To overcome this collective action problem and to achieve the result that Congress has determined is best for all employees, the FLSA should apply to this group of workers when they meet the court-created tests of employment.

\footnotetext{
${ }^{123}$ Id at 29.

${ }^{199}$ Brooklyn Savings Bank v O'Neil, 324 US 697, 707 n 18 (1945).

${ }^{160}$ Cass R. Sunstein, Free Markets and Social Justice 61 (Oxford 1997).
} 
Finally, a minimum wage may promote more participation in, and thus help ensure greater success of, welfare-to-work programs. Just as lowering the benefit reduction rate will increase the work effort of welfare recipients, ${ }^{141}$ ensuring a minimum wage will provide those on welfare with a greater incentive to participate in workfare at an earlier stage.

2. Ensuring fair competition among employers and in the marketplace.

Allowing employers to use workfare as a cheap labor source may undermine the FLSA's goal of preventing certain employers from gaining a competitive advantage in the marketplace by paying subminimum wages. For example, in Archie $v$ Grand Central Partnership, Inc, ${ }^{142}$ a recent case involving the employment of homeless persons in New York's Pathways to Employment ("PTE") Program, the district court held that the workers were "employees" under the FLSA based on the "economic reality" of the situation. ${ }^{143}$ In addition to the fact that PTE participants often displaced regular employees, the court found it significant that paying the participants below the minimum wage allowed the employer to meet contractual obligations it could not have met without the program. ${ }^{144}$

While PTE was not a state workfare program, many of its goals, such as training and rehabilitation, would also be present in the state context. Thus, the economic concerns of the district court should be instructive for workfare issues as well. When asked to determine whether particular workfare participants are FLSA "employees," courts should look to the economic advantages gained by the employer as an indication that in "economic reality" the relationship is one of employment.

\section{B. Policy Arguments Against Application of the FLSA to Workfare Participants}

While policy considerations point in favor of considering workfare participants "employees," some critics assert that ap-

\footnotetext{
${ }^{11}$ See Robert Moffitt, Work and the U.S. Welfare System: A Review 43-46 (University of Wisconsin-Madison Institute for Research on Poverty 1988). As Moffitt notes, "By lowering the benefit reduction rate, recipients are allowed to 'keep' a higher percentage of their earnings-that is, their benefit is not reduced by as great an amount if they earn more. Thus, a direct financial inducement to work is provided." Id at 44. The benefit reduction rate works essentially like a tax.

${ }^{12} 997$ F Supp 504 (S D NY 1998).

${ }^{13}$ Id at 535.

is Id.
} 
plying FLSA to participants will result in undesirable consequences. Although recognizing that the logic of the Tenth Circuit's decision in Johns was somewhat flawed, some commentators have supported the court's holding. ${ }^{145}$ For example, a recent Note suggests that treating workfare workers the same as other state employees would require states to allow these workers to unionize, and that "[i]f workfare workers were allowed to join unions, there would be an economic disparity between workfare program participants and regular employees." ${ }^{146}$ The disparity apparently would come from lower tax burdens on workfare participants as compared to regular state employees. ${ }^{147}$

This argument is flawed for two reasons. First, it assumes that extending FLSA minimum wage coverage to workfare participants necessarily requires that all federal labor law protections apply to them. As noted earlier, however, courts consider the FLSA's definitions of "employee" and "employ" to be the broadest in any labor statute, ${ }^{148}$ and courts can choose to draw the line between this broad remedial statute and other federal employment laws that have not been held to incorporate such a broad definition of employee. Second, application of federal labor laws does not create the disparity between workfare and regular employment; instead, this is a product of unequal taxation..$^{149}$

A more serious criticism of the application of FLSA minimum wage protection to workfare is that requiring employers to pay higher wages may result in fewer welfare recipients being employed, a situation that could block the potential for higher participation rates discussed earlier. Yet the same argument can be made about the minimum wage in general, ${ }^{150}$ and Congress implicitly rejected this concern when it passed the FLSA. Also, be-

\footnotetext{
${ }^{145}$ See, for example, John P. Collins, Jr., Note, Developments in Poverty: Welfare Reform, 16 Yale L \& Pol Rev 221, 260 (1997) (criticizing the court's reliance on the fact that state workfare participants do not go through the same application process or get paid in the same way as other state employees for essentially "employ[ing] this difference as a conclusion").

${ }^{146} \mathrm{Id}$.

${ }^{167}$ See id.

${ }^{143}$ See text accompanying note 56.

${ }^{49}$ Unequal taxation is the source of the apparent disparity because, the Note argues, workfare participants "presumably would not have the same tax burden as regular civil service employees" as they "do not pay withholding taxes as do state employees." Collins, Note, 16 Yale L \& Pol Rev at 260 (cited in note 145). The proper remedy for this disparity, however, would be modifying the tax code, not denying minimum wage application to an entire group of workers.

${ }^{150}$ For an economic analysis of the disemployment effects of the minimum wage, see Richard A. Posner, Economic Analysis of Law § 11.6 at 361-63 (Aspen 5th ed 1998) (arguing that the minimum wage increases the price of labor and therefore decreases the demand for that labor, and summarizing empirical literature on both sides of the debate).
} 
cause poverty may be the largest problem faced by participants trying to break from welfare dependency ${ }_{1}^{151}$ it is more important to ensure that at least some workfare participants are successful in coming off the welfare rolls. Professor Sunstein notes a related argument in favor of increasing the minimum wage in order "to guarantee that work will be sufficiently remunerative to keep people out of poverty and to send a signal about the importance and value of work, thereby increasing the supply of and demand for labor. These effects might outweigh any unemployment effect." ${ }^{152}$

Finally, critics have argued that workfare participants are different from regular employees because they

may be less efficient in performing their tasks . . . because they have little incentive to devote their full energy to the jobs they are assigned. Second, they may need more supervision [than] the average employee because they may not have held previously a full-time job or been trained to be disciplined workers. ${ }^{153}$

While these arguments may be true in some cases, they do not mean that FLSA should never apply to workfare participants. Even when these are accurate descriptions of a particular workfare participant, they are only a few of the many factors that courts should consider. The district court in Archie noted that "[t]here is no doubt that the PTE participants would have had great difficulty in obtaining jobs in the private sector, ${ }^{, 154}$ but nonetheless held that those participants were employees entitled to the FLSA's minimum wage. As noted earlier, the court found it significant that these participants were doing the work of other employees and that the employer derived financial benefit from their work. ${ }^{155}$ Also, given the bargaining power inequities and the collective action problem discussed earlier, there are sound public policy reasons to require the statutory minimum wage that may outweigh the critics' arguments.

\section{CONCLUSSION}

The apparent gap in the nondiscrimination provisions of the PRWORA could prove to be a stumbling block for states' welfare-

\footnotetext{
${ }^{251}$ See text accompanying notes $132-34$.

${ }^{152}$ Sunstein, Free Markets at 283 (cited in note 140).

${ }^{153}$ Collins, Note, 16 Yale L \& Pol Rev at 259 (cited in note 145).

${ }^{154} 997 \mathrm{~F}$ Supp at 533.

${ }^{155}$ Id at 533, 535.
} 
to-work initiatives. Courts should not categorically deny FLSA coverage to workfare participants who perform the same tasks as other protected "employees," but should instead analyze the nature of the relationship on a case-by-case basis in the context of the FLSA's broad remedial goals. While some participants in workfare programs such as vocational training or job search activities may not meet the definition of "employee" as developed by either the Bonnette four factor or "whole activity" approaches, most other workfare participants will qualify. Courts should protect the purposes behind the FLSA-guaranteeing minimum working conditions and eliminating unfair competition among employers-by ensuring that these participants receive the statutory minimum wage for their work. This will further the policy goals of the PRWORA by providing welfare recipients with greater incentives to participate in workfare programs and a better chance of breaking the cycle of dependency. 